\title{
China's Internet Financial Risks and Risk Prevention Research
}

\author{
Xinyang Kan, Jianping Wu, Qingjun Meng \\ Business College of Hohai University, Hohai University, Nanjing, China \\ Email: 1186069051@qq.com
}

Received 16 July 2015; accepted 1 August 2015; published 4 August 2015

Copyright (C) 2015 by authors and Scientific Research Publishing Inc.

This work is licensed under the Creative Commons Attribution International License (CC BY).

http://creativecommons.org/licenses/by/4.0/

c) (i) Open Access

\begin{abstract}
The Internet finance is a new model of finance. It has many characteristics, such as high-efficiency, immediacy and universality. Although it appeared not early in China, the Internet finance develops promptly both in the scale and speed. Due to the lack of correspondent legal systems and mature technologies, there are legal risks, operational risks, business management risks and technical risks. Making perfect Internet financial laws and regulations, introducing the supporting policies for the development of the Internet financial industry, and strengthening the industry self-discipline are the key to reducing the Internet financial risk.
\end{abstract}

\section{Keywords}

Internet Finance, Prevalent, Risk, Precaution

\section{The Development of the Internet Finance and Its Research Value}

\subsection{The Development of the Internet Finance}

Internet finance is relying on the payments, cloud computing, social networking and search engine, app and other Internet tools to achieve a financing, payment and information services in the emerging finance. As an emerging field of Internet finance has become an integral part of our existing financial system. Internet finance has many advantages, such as a high degree of transparency during the operation, widely participants and low cost, simplify the payment process, etc. [1]. The current Internet finance has already seeped to each domain, including banking, insurance, funds and securities firms, among which are the fastest growing online payment, mobile banking and P2P financing model [2]. Mobile banking functions from mobile payment loans extend to deposit basic financial services, and P2P financing pattern can, to a certain extent, solve the problem of micro, small and medium enterprises financing. It is expected to serve as a useful supplement the existing banking system. 


\subsection{The Necessities on Researching Internet Finance}

The growing Internet financial development leads to the traditional financial market operating pressure that is more and more fierce, even with the development of this trend, and that can eventually lead to the emergence of a new business model and operation pattern of traditional financial market, and affect the future development direction of traditional financial markets. This new convenient services have brought great impact on the wellcapitalized traditional financial market. In 2013, for example, Yu'ebao as the representative of Internet financial products forms a larger impact on traditional banks. Statistical data from the central bank shows that in January 2014 within the banking system total reduction of RMB 940.2 billion yuan savings deposits is compared to the same period increased by 205 billion yuan less. Such as Alibaba and Celestica fund launched Yu'ebao, which size has exceeded 100 billion yuan in less than half a year [3]. Finance through Wechat launchs in less than a week's time to break through 10 billion fund size. Alipay subsequent launch of lantern financial products in less than ten minutes sell out and so on. Including third-party payment, P2P network lending, represented by the Internet fiinance, there is a tendency to traditional financial industry challenges.

\section{Relevant References Review and Researches}

Li Keqiang (2014) during his government work report that the promotion of the healthy development of Internet finance, improve financial supervision and coordination mechanism to closely monitor cross-border capital flows, hold the bottom line is not systemic and regional financial risks. Make financial become a pool of running water, better irrigation of small and micro enterprises, "three rural" and the real economy of the tree". "Promote the healthy development of Internet banking", which will undoubtedly become a positive sign internet banking for sustainable development. It means that Internet finance officially entered the decision-making horizons, adding to China's economic and financial development of the sequence, in China's economic and financial development of enormous potential financial innovation strength for the development of China's financial industry has opened a new door. Li Dongrong (2014) thought that the Internet finance as a new thing, to play its positive role in normal development, and said the central bank will support new things. And encourage and finance the development of the Internet at the same time, the risks of Internet finance also had great concern. Yang Kaisheng proposed, whether online or offline, as long as the substance is financial activities, they should be regulated in accordance with the scope of the existing financial regulations, instead of "laissez-faire, something happens to say" attitude. Former member of the Monetary Policy Committee, Li Daokui also stressed the need to incorporate Internet banking regulation, and believe the Internet should be introduced interim financial regulations. Wang Jingwu also believed that the current Internet more hidden financial risks and legal status is not clear, and drifted away from the financial regulatory system, the financial system security, social stability have a significant impact, strengthen financial supervision has been pressing the Internet.

With the further development of the Internet finance, more and more scholars to analyze Internet financial risks, and are actively looking for countermeasures. He Wenhu (2014) [4] thought Internet risk mainly include legal risks, technology security risk, operation risk, cross-border risk, operational risk, etc. Proposed on the basis of the mode of Internet financial characteristics and forms, with the characteristic of the Internet financial risk on, main types and causes of financial risk supervision system of the Internet. Xionghuan Yan (2014) [5] believed that the Internet financial risks include technology risk and business risk, financial risk prevention to strengthen the Internet need to build Internet financial security system. Yan Zhenyu (2013) [6] believed that the Internet financial risks include legal and policy risk, operational risk management, network technology risks, monetary policy risk and money laundering risk and other types of current China's Internet financial risk, although overall control, its development trend requires close attention, respond prudently. Li Rensen (2015) [7] thought that China's Internet finance main face legal risk, technology risk, business risk, clear Internet financial risk supervision responsibility is top priority.

Literature review and research found that Internet financial officially entered the policy makers view, added to China's economic and financial development sequence, for China's economic potential financial innovation of the huge force in financial development, at the same time, as a new thing, there are risks of Internet financial again, review the scholars study found that particularly common legal risks, technology risks, in view of the Internet financial status, risk also rises increasingly rising of the status quo, I start with the Internet of the financial risk and risk response measures. 


\section{Risks in the Development of the Internet Finance}

\subsection{The Legal Risks}

The current legislative work of Internet finance is still in the initial stage, whether in the present legislative constraints, how the legislation has not yet formed a unified opinion. In the existing legal norms related to Internet financial roughly divided into three categories, which aims to encourage and support the development of the Internet financial norm, such rules sporadic referring to administrative rules and regulations promulgated by the state council and ministries of the state council department regulations, local governments in the normative documents. Such as the people's bank of China issued "China's financial sector informatization" twelfth five-year "development plan". Secondly, Scattered regulations related to Internet financial consumer interest protection, such provisions referring to "consumer rights and interests protects a law", "the people's bank of China" and "commercial bank law", "securities law", "securities investment fund law", "insurance law" and other laws. Thirdly, sporadic associated with Internet financial infrastructure construction specifications. Such as "electronic signature law", "electronic banking business management method", etc. Although the above three kinds of laws and regulations on Internet financial risk supervision of our country has a certain regulation effect, the Internet financial at present the biggest legal risk is still a lack of clear and concrete regulations.

\subsection{The Operational Risks}

In the Internet finance security systems, the Internet financial risk management system, authorize the use of the Internet account, in the Internet financial services institutions and exchanges of information and Internet security operations customers have great relevance. If the Internet trading subject appears in the process of operation error, may lead to business risks [8]. Because the Internet financial business is conducted in a virtual environment, trade subject for the Internet financial services operating requirements, operating specifications, operating procedures and other aspects not know enough about the subject transaction process transactions generated operational errors, greatly reducing the financial security of the Internet sexual, financial services to Internet risks.

\subsection{The Business Management Risks}

Since the current Internet finance providers, many of which are entered by a non-traditional financial sector, in the subjective to the lack of attention to financial risks, neglect of business management, especially in the absence of source management system. For example, online financial products too high expected returns but then its risk warning not enough, Internet loan companies do not have the risk reserves, some third-party payment institutions to verify the customer's identity at the time of user registration procedure is relatively simple, P2P institutions undertake financing, funding agency and guarantee functions, and no capital constraints, there is a big risk, net loan companies escape event has occurred [9]. On the other hand, when the dramatic changes in the market environment, due to the liquidity risk generated by inadequate preventive operations, financial security risks, such as third-party payment delay settlement of net used in a time lag, if possible mismanagement and further lead to liquidity risk. Credit payment services in advance but also by third-party payment agencies, which also faces credit risk.

\subsection{The Technical Risks}

Internet finance is based on computer technology, network technology and information technology. In the process of carry out and implement the financial business technology applications, it's crucial. For example, open network communication systems, inadequate security key management and encryption technology, TCP/IP protocol is poor, combined with computer viruses and hacker attacks expert, can easily cause financial losses are subject of the transaction [10]. In addition, China's Internet financial software and hardware systems are mostly drawn from abroad, the lack of Internet financial facilities with high-tech intellectual property rights, on the overall financial security also have a certain threat.

\subsection{The Lack of Internet Financial Talents and the Deviation of Public Opinions}

Internet finance is a young field, many Internet financial institutions are in a rapid expansion, rapidly growth in the number of practitioners, personnel quality not neat, potentially larger operating risk and moral risk. Even 
some financial institutions use Internet finance malicious currying vulnerabilities, making profit by precipitation misappropriation of funds and money laundering. Because of the Internet finance is still in its infancy, a lot of exposure is not sufficient. In the temptation of high returns, many investor perceptions of risk are not into place, the Internet financial stakeholders lack of risk awareness. Social media has a deviation in the publicity. Early emphasis on propaganda on the Internet is an innovative financial products, particularly high income, while ignoring the risk of its investment.

\section{The Countermeasures of Reducing the Risks of Internet Financial Development}

\subsection{Perfecting the Relevant Laws}

Improving the existing laws and regulations, such as increasing the intensity of punishment to the Internet crime, and clearing the civil liabilities one should bear for causing the Internet financial risks. At the same time the Internet fair trade rules should be made, as well as the identification of digital signature, saving electronic transaction vouchers, protection of consumers' personal information, clarifying the responsibility of the trading subjects' side make detailed provisions, so as to ensure the orderly conduct of the Internet financial business. As for Internet financing services, network lending laws and regulations is need to formulate, the category of network lending is need to clear as soon as possible, clarifying its legal place, scope of business and management requirements, regulatory responsibilities, etc. And formulating relevant laws and regulations as soon as possible.

\subsection{Promoting the Cooperation of Internet Financial Regulatory}

To carry on comprehensive Internet financial risk supervision, timely coordination pattern differentiated and mixing two kinds of supervision. Proposal led by the people's bank of China, "three commissions" (China Banking Regulatory Commission, China Securities Regulatory Commission, China Insurance Regulatory Commission) and the industrial and commercial departments such as relying on the existing credit system together, structured data collection by the traditional financial institutions and the Internet financial enterprises structured, semi-structured, and unstructured data, using big data technology to establish the Internet financial companies pay to use the public Internet credit system [11]. At the same time, strengthen international cooperation in financial supervision between Internet, promote the development of a unified regulatory standards, strengthen international communication and coordination.

\subsection{Introducing Supporting Policies for the Internet Financial Industry's Development}

The status of Internet financial industry is increasing in the Financial Reform. On the basis of investigations and studies, introduced a package of industrial development policy as soon as possible, to regulate and guide the financial development of the Internet. On the premise of risk control and inclusive development, in view of the Internet financial and related logistics, big data, mobile communications and other industries do overall consideration. In development planning, tax incentives, access to facilities, system construction, personnel training, management and other aspects of the industry, specific and strong policy-oriented measures should be introduced as soon as possible.

\subsection{Improving the Internet Information Technologies}

Establish technical standards of Internet banking, and further improve the financial industry a unified technical standard, enhanced coordination of network financial system is conducive to monitoring and prevention of risks, and with international standards on a computer network security standards and norms as soon as possible. Actively integrate various resources, using large collaborative ideas. To establish a customer-centric Internetshared financial database and analysis through a database to classify and organize and monitor business processes [11]. In hardware and software, research and development efforts of proprietary information technology, practical technology such as firewalls, data encryption, and smart card technology has improved in key technologies, to reduce dependence on the developed countries, establish a network security system.

\subsection{Fostering Interdisciplinary Talents and form a Fair Atmosphere Public Opinion}

To train interdisciplinary talents, Internet finance regulators should encourage enterprises to increase network 
technology transfer, research and development investment in transformation, both familiar to come to train a group of computer network and communication technology through innovative personnel training methods and channels, and familiar with the financial practices of the compound talents. Through the fair public opinion propaganda, strengthen industry self-discipline, enable participants in using this kind of financial innovation products pay attention to risk prevention, to improve the level of investment and financing.

\section{Conclusion}

With the deepening integration of network and finance, China's Internet finance is becoming a new financial format. Although Internet finance can expand business scope, reduce financial cost, and improve the financial business that is dealt with speed, but its existence in the technical risk, business risk and legal risk brings a great threat to the Internet financial. In this regard, perfecting relevant laws and regulations, perfecting through Internet information technology to train compound talents in order to promote China's Internet financial create conditions for better and faster development.

\section{References}

[1] Xiong, H.Y. and Liu, J.Q. (2014) Internet Financial Risks and Risk Prevention Research. China Business \& Trade, 11, 97-98.

[2] Lin, Z.Y. (2014) Internet Financial Model and Risk Regulatory Thinking. Modern Business, 12, 155.

[3] Wu, X.Q. (2014) The Logic of Internet Financial. China Finance, 3, 29-31.

[4] He, W.H. (2014) Supervision and Management of Internet Financial Risks in China. Journal of Financial Development, 458, 45-49.

[5] Zhang, J. (2014) Internet Financial: Emerging Formats, Potential Risk and Response. Inquiry into Economics Issues, 4, 81-85.

[6] Yan, Z.Y. (2013) Some Thinking about the Current Internet Financial Risks. Zhejiang Finance, 12, 40-42.

[7] Li, R.S. (2015) Thinking about China’s Internet Regulation of Financial Risk. China CIO News, 2, 105-106.

[8] An, B.K. and Ruan, J.Y. (2014) Internet Financial, Regulatory and Legal Principles. Financial regulation, 27, 57-69.

[9] Zhuang, B.C. and Wang, Z.Y. (2014) Internet Financial Risk Prevention and Developing Trends of Research in China. Times Finance, 552, 66-68.

[10] Feng, J.S. (2009) Network Financial Risk: The Regulation Situation and Improving Countermeasures of China. Finance Teaching and Research, 123, 41-44.

[11] Yang, H., Yi, D.H. and Xiao, H.W. (2014) Based on Large Data Analysis of Internet Financial Risk Early Warning Research. Modern Management Science, 4, 3-5. 